participation in the E.E.C. ? The Common Market countries are considering restrictions in the use of antiobitics. Some have already attempted to do so, but without a common policy the movement of foods, animals, and peoples between the various countries will reduce the effectiveness of the U.K. precautions. And what of the rest of the world? The W.H.O. information centre will help to collect data, but strong measures are needed until effective means are found to remove $\mathbf{R}$-factors and plasmids from bacterial cells under natural conditions. In the meanwhile complete agreement should be established that our most powerful drug weapons will be used in their truly curative role to destroy and not to maintain infectious agents causing acute disease. 1 Working Party on The Public Health Aspects of Antibiotics in Feedstuffs.

Smith, H. W., and Linggood, M. A., fournal of Medical Microbiology, $1971,4,487$.

3 Anderson, E. S., British Medical fournal, 1968, 3, 33.

- Anderson, E. S., Acta Microbiologica Hellenica, 1973, 18, 200

5 Jacobs, S. I., et al., Archives of Disease in Childhood, 1970, 45, 656.

- Rowe, B., Taylor, J., and Bettelheim, K. A., Lancet, 1970, 1, 1.

7 Smith, H. W., Fournal of Medical Microbiology, 1973, 6, 347.

8 Joint Committee of Department of Health and Social Security and Ministry of Agriculture, Fisheries and Food, Use of Antibiotics in Animal |Husbandry and Veterinary Medicine, Report. Cmnd. 4190. London, H.M.S.O., 1969.

\section{Sleeping Sickness}

For more than 50 years studies of the epidemiology of sleeping sickness have been hampered by the problems of differentiating the causative organism of East African sleeping sickness, Trypanosoma brucei rhodesiense, and that of Gambian sleeping sickness, T.b.gambiense, from T.b.brucei, the morphologically identical parasite common in game and domestic animals which is not infective to man. What is needed is some means of determining the infectivity to man of strains which may be isolated from game and domestic animals, and thus to be able to assess the danger to health for men living or working in areas where such animals exist. Up to three years ago the only method available for differentiating T.b.brucei from T.b.rhodesiense was the use of human volunteers, who were used extensively in East Africa to test isolates originating from animals and from Glossina. A test was developed in 1970 by Rickman and Robson ${ }^{1}$ which made use of the fact that organisms from T.b.brucei strains are lysed after incubation with human serum. This test, the blood incubation infectivity test (B.I.I.T.), has been extensively investigated since it was first developed and modifications to the original technique proposed. Difficulties still remain, however, in the interpretation of so-called equivocal results which have been frequently obtained, and the B.I.I.T. has been used to categorize strains before human volunteers have been employed in a final test of infectivity to man. This fact alone indicates that the test is not absolutely reliable and does not enjoy the confidence of some workers. An excellent discussion on the limitation and use of the technique, based on the latest information, has recently been published. ${ }^{2}$

This problem of differentiating organisms dangerous to man is mainly one which confronts workers in Eastern Africa; in West and Central Africa the main problem for those working on human trypanosomiasis is the need for a rapid, efficient technique for screening large numbers of persons who may have early subclinical Gambian trypanosomiasis, while there is also a need for a technique which may allow any possible animal reservoirs of the disease to be identified. The fluores- cent antibody technique has been used successfully for detecting early cases in Zaire ${ }^{3}$ - these are not capable of parasitological diagnosis during the early stage of the disease. This test has also been used in Liberia. ${ }^{4}$ Its great advantage is that blood can be taken on filter paper and it is, therefore, simple and rapid and many suspects can be sampled daily. It is also more specific than elevated serum IgM levels in Gambian sleeping sickness.

The differentiation of the subspecies of T.brucei by a fluorescent antibody technique has recently been reported by Latif and Adam, ${ }^{5}$ who were able to differentiate the three trypanosomes, T.b.rhodesiense, T.b.gambiense, and T.b.brucei on the basis of marked differences of the antibody endpoint titres against homologous and heterologous sera. This method of differentiation may not appeal to protozoologists, but the results seem convincing enough to suggest it will be reliable for field work especially if used in conjunction with the B.I.I.T. A further valuable tool still remains to be fully exploited in the differentiation of T.brucei subspecies. Recent work has made it possible to detect strain as well as specific differences in the isoenzyme pattern of the parasite aminotransferases in the ungulate trypanosomes $T$. vivax and $T$. congolense and the rodent trypanosomes T.lewisi and T.musculi. Other new techniques of biochemical taxonomy include the use of buoyant density of nuclear and kinetoplast DNA in caesium chloride gradients and the prospect of the development of a DNA: RNA slide hybridization technique for field use in trypanosomiasis - and possibly in leishmaniasis; if some or all of these techniques prove reliable in the field rapid progress should be made in the epidemiology and control of these parasites.

\footnotetext{
1 Rickman, L. R., and Robson, J., Bulletin of the World Health Organiza-

tion, 1970, 42, (4), 650.
2 Hawking, F., Transactions of the Royal Society of Tropical Medicine and Hygiene, 1973, 67, 517.

8 Wery, M., Van Wettere, P., Wery-Paskoff, S., Van Meirvenne, M., and Mesatewa, M., Annales des Societes Belges de Medecine Tropicale, de Parasitologie et de Mycologie, 1970, 50, 711 .

4 Lucasse, C., Tropical and Geographical Medicine, 1970, 22, 227

5 Latif, B.M.A., and Adam, K.M.G., Bulletin of the World Health Organization, $1973,48,401$.

6 Kilgour, V., and Godfrey, D. G., Nature New Biology, 1973, 244, 69.
}

\section{Looking after Schizophrenics}

By 1975 half our mental hospitals, described by Mr. Enoch Powell when Minister of Health with more eloquence than accuracy as: "majestic, brooding structures, dominated by the twin ideas of isolation and custodialism, housed in depressing and decaying buildings, suffering from acute staff shortages," should have been pulled down and their function split between psychiatric units in general hospitals and community care-if the 1962 Hospital Plan ${ }^{1}$ is carried through as originally intended. At first the plan was welcomed by the vast majority of British psychiatrists. Indeed, it was considered that to oppose it was reactionary if not sacreligious. Those who did oppose it had doubts not about the doctrine but about the accuracy of the statistical analyses on which the future needs for beds in mental hospitals were based, and about the extent and speed with which the local authorities would make good the recommendations incorporated in the Mental Health Act, 1959. Implicit in these recommendations was the need to set up prophylactic services and all types of community care for those not needing to be treated in hospital: residential training centres, hostels, and general social help 
or advice. Unfortunatly no date was set when these obligations had to be met.

In the ensuing years evidence has accumulated to substantiate the doubts about the original statistics. As long ago as 1966 Early and Magnus ${ }^{2}$ alleged that the predictions ${ }^{3}$ on which official policy was based seemed unlikely to be achieved and that it was doubtful if the Hospital Plan could continue to be based on those figures. But while statisticians wrangled the run-down of mental hospitals proceeded. Between 1960 and 1969 the hospitals lost 24,000 beds. $^{4}$ Last year we asked ${ }^{5}$ for a full investigation of the quality of life now enjoyed by the patients who might otherwise have continued to occupy these beds. The data quoted then bear repeating. The latest official count of hostel places ${ }^{6}$ provided by local authorities is little more than 2,000. Those provided have come under strong criticism in a Fabian pamphlet. ${ }^{7}$ Individuals unable to find refuge in hostels gravitate to common lodging houses and reception centres. Of the 1,400 mentally ill men circulating annually from Camberwell Reception Centre the majority were found to have been inpatients in mental hospitals $;^{8}$ and in a survey of homeless people carried out on a single December night the National Assistance Board ${ }^{9}$ estimated that $10 \%$ of the total of 26,884 men and 10,905 women were mentally ill.

Again, there has been a startling rise in the past decade ${ }^{10}$ -from 6,366 in 1961 to 13,499 in 1971 -in the number of prisoners remanded in custody for a medical report, almost invariably psychiatric. A major remand prison in London reported in 1970 on 3,609 male prisoners of whom $512(14 \cdot 18 \%)$ had been under care in psychiatric hospitals within 12 months of their reception. Similarly, there is evidence of a substantial increase in the number of mentally abnormal offenders dealt with by the police without prosecution under, for example, Section 136 of the Mental Health Act. In 1965 the twelve hospitals administered by the South-west Metropolitan Regional Hospital Board admitted 308 such cases representing $1.9 \%$ of all admissions, but in 1969 the figure rose to 644 , or $3.9 \%$ of all admissions. Rollin ${ }^{11}$ has shown that $67 \%$ of his sample of unprosecuted mentally abnormal offenders admitted to one of the twelve hospitals, mostly under Section 136 , had been previously treated in mental hospitals.

It is apparent that the socially retrogressive ways in which patients discharged from mental hospitals are redistributed apply mainly to those who have no home or who have unsatisfactory homes. As a corollary it might be assumed that a warm, welcoming home would offer optimum conditions for the returning ex-patient. "No place like home for rehabilitation" could be another seductive slogan and mean as much or as little as its counterpart "community care." But even under optimum conditions the major psychoses usually persist in following their predetermined course. Schizophrenia in particular, still one of the major scourges of mankind, is a chronic disease with alternating remissions and relapses, producing in the majority of cases evidence of ever-increasing damage to the personality. The potential for self sufficiency or "rehabilitation" will vary inversely with the degree of damage and directly with the support from the family and the community. If the family burden is too great or the community support inadequate then not only will the patient suffer but the family may go under too.

Precisely these points have been made with telling and poignant effect in the first report $^{12}$ of an organization -the National Schizophrenia Fellowship-which has the support of the Department of Social Psychiatry of the Institute of Psychiatry, London. In his foreword John Pringle, honorary director of the fellowship, does not pull his punches. He castigates those whose duty it was: "to provide the community support, in replacement for custodial care, which many chronic sufferers [from schizophrenia], unable to find for themselves, cannot do without." He goes on: "The closure of mental hospital wards, which at least provide the basic minimum shelter and life support, goes ruthlessly on, leaving nothing in their place."

The body of the report contains a series of accounts of relatives, mainly parents, of what it is like to live with schizophrenia. The burning desire to do what is right shines through the pages, but if there is a common theme it is that there are promises and more promises of help from innumerable agencies but in the end the relatives must go it alone. "The effect of having George at home on our home life has been disastrous," typifies several examples of the way one schizophrenic can wreck the social life of an entire family. "I do not think 'the community' exists", is the sad reflexion of a mother whose daughter has encountered "the sneers, no job, cold shouldering, impatience and general feeling of being out of step." "I have found that every hospital wants to discharge my son at the first opportunity," is a wry comment on current administrative policy obtaining in so many mental hospitals today. "On three occasions, when she reacted unfavourably to long lasting injections of Modecate, I have had to call the police as she went beserk and literally threw furniture around," describes very dramatically the unpredictable violence of some chronic schizophrenics. "All of the other colleges have rejected me without interview, and I feel that admission of schizophrenia is being held against me," is the sad reflexion of a graduate who wanted to become a school teacher. "There is, therefore, virtually nothing available in the way of after care, rehabilitation or training for the schizophrenic in this immediate area," a caustic statement requiring no further comment.

These direct quotations give weight to the cri-de-coeur made in the foreword: "Cannot a humane society do better than this for one of the most vulnerable and least befriended sections of its people ?" It can, but it remains to be seen if it will. But until such time as the concept of community care is translated into a reality the powers-that-be would be well advised to follow the advice of the Tripartite Committee ${ }^{13}$ which recommended: "In general no closure of existing psychiatric hospitals should be contemplated. Their future requires much further study, and meantime they should be sustained in every way and should be given priority in the allocation of resources until adequate alternative services of high quality are available and are functioning successfully."

1 A Hospital Plan for England and Wales. London, H.M.S.O., 1962, Cmnd. 1604

2 Early, D. F., and Magnus, R. V., British fournal of Psychiatry, 1966, 112, 595 .

3 Tooth, G. C., and Brook, E. M., Lancet, 1961, 1, 710

4 Department of Health and Social Security, Psychiatric Hospitals and Units in England and $W$ ales. Inpatient statistics from the Mental Health Enquiry for the Year 1969. London, H.M.S.O., 1971.

${ }^{5}$ British Medical fournal, 1973, 3, 1.

6 Local Authority Social Services Departments, Mental Health Statistics at 31 March 1972, England, Statistics and Research, Division 6, London, H1. March 1972,

7 Durkin, E., Hostels for the Mentally Disordered. Young Fabian Pamphlet 24, London, Fabian Society, 1971 .

8 Tidmarsh, D. in Evaluating a Community Psychiatric Service: The Camberwell Register 1964-71, ed. J. K. Wing and A. M. Hailey, Nuffield Provincial Hospitals Trust. London, Oxford University Press, 1972.

- Ministry of Social Security, National Assistance Board, Homeless Single Persons. London, H.M.S.O., 1966.

10 Home Office, Report of the Prison Department for the Year 1961 and Report of the Prison Department for the Year 1971. London, H.M.S.O., 1962 and 1972 .

11 Rollin, H. R., The Mentally Abnormal Offender and the Law. Oxford, Pergamon, 1969.

12 Living with Schizophrenia. Surbiton, Surrey, National Schizophrenia Fellowship, 1974

13 Tripartite Committee (Royal College of Psychiatrists, The Society of Medical Officers of Health, and the British Medical Association), The Mental Health Service after Unification. London, B.M.A., 1972. 